\title{
DOSSIER CROSSCHECK AS A LEGITIMIZATION STRATEGY OF THE JOURNALISM FIELD IN RESPONSE TO FAKE NEWS
}

Copyright $\odot 2019$ SBPjor / Associação Brasileira de Pesquisadores em Jornalismo
MARIA IVETE TREVISAN FOSSÁ

Universidade Federal de Santa Maria, Rio Grande do Sul - Brazil

ORCID: 0000-0001-6536-6714

KAUANE ANDRESSA MÜLLER

Universidade Federal de Santa Maria, Rio Grande do Sul - Brazil

ORCID: 0000-0002-5688-9385

DOI: 10.25200/BJR.v15n3.2019.1196

Received on: 28/02/2019| Approved on: 24/08/2019

ABSTRACT - This work aims to understand Projeto Comprova as a legitimation strategy of the journalistic field. We also propose an initial approach with the crosscheck experience, during the debate about fake news. The principal strategy used in this case is credibility, which is obtained in a deal between journalism and society. This deal allows a trust relationship. At Projeto Comprova, there is a concern in detail the verification process, which causes a modification in the narrative order. Besides, in the fake news context, the idea of news itself changed in checking business. In the digital ambience, there is a modification in the narrative built with emphasis in the verification of facts or data: if the journalistic companies classify some information as false, it becomes news.

Key words: Journalistic field. Legitimation strategies. Checking. Crosscheck.

\section{A CHECAGEM CRUZADA COMO ESTRATÉGIA DE LEGITIMAÇÃO DO CAMPO JORNALÍSTICO EM REAÇÃO ÀS FAKE NEWS}

RESUMO - Este estudo tem por objetivo compreender o Projeto Comprova como estratégia de legitimação do campo jornalístico e propor uma primeira aproximação com a experiência de checagem cruzada, em meio ao debate sobre notícias falsas. A principal estratégia acionada nesse caso é a de credibilidade, obtida num acordo entre jornalismo e sociedade, que permite que seja estabelecida uma relação de confiança. No Projeto Comprova, há uma preocupação por detalhar o processo de apuração, causando uma modificação de ordem narrativa. Além disso, a partir da noção de fake news, modifica-se a própria ideia do que é notícia em iniciativas de checagem, de modo que a narrativa construída com ênfase no processo de apuração de fatos ou de dados na ambiência digital transforma a classificação de uma informação como falsa pelas organizações jornalísticas na própria notícia.

Palavras-chave: Campo jornalístico. Estratégias de legitimação. Checagem. Crosscheck. 


\section{EL CHEQUEO CRUZADO COMO ESTRATEGIA DE LEGITIMACIÓN DEL EN- TORNO PERIODÍSTICO COMO REACCIÓN A LAS FAKE NEWS}

RESUMEN - Este trabajo tiene como objetivo comprender el Projeto Comprova como estrategia de legitimación del entorno periodístico y proponer una primera aproximación con la experiencia de chequeo cruzado, en medio a discusiones sobre noticias falsas. La principal estrategia accionada es la de credibilidad, obtenida en un acuerdo entre periodismo y sociedad, que permite establecer una relación de confianza. En Projeto Comprova, hay la preocupación en detallar el proceso de apuración, lo que causa una modificación de orden narrativo. Además, a partir de la noción de fake news, se cambia la propia idea de lo que es noticia en espacios de chequeo, de modo que la narración construida con énfasis en el proceso de apuración de hechos o de datos en el ambiente digital transforma la clasificación de una información por las empresas periodísticas como falsa en la propia noticia.

Palabras clave: Campo periodístico. Estrategias de legitimación. Chequeo. Crosscheck.

\section{Preliminary considerations}

The debate over fake news was highlighted in the 2016 US elections context, when the then Republican presidential candidate Donald Trump accused national and international press of producing fake news to harm him. The term fake news, used by Trump in these accusations, has started to circulate in several other countries to refer to fake news generally produced for or against a cause related to electoral politics, celebrities, health, crime and other topics.

The fake news debate has been affecting journalism as the term has also been used accusingly in order to delegitimize its work. During the 2018 Brazilian electoral process, at the height of discussions about fake news in Brazil, many agencies and institutions announced their concern about the phenomenon and its possible political-electoral impact. Meanwhile, Folha de S.Paulo, one of the largest and most traditional Brazilian newspapers, was accused by the elected president - at the time, presidential candidate of the Liberal Social Party (PSL) - Jair Bolsonaro for producing fake news (Marques, 2018), in a movement similar to the one that happened in 
the US elections. This movement was repeated and extended to other journalistic organizations.

Although politics is not the only subject of fake news production, it seems to be one of the issues causing concern in the press due to a possible electoral impact. Even before this debate had gained momentum, since the 2000 s, several checking initiatives to verify the veracity of the information circulating on social networking websites have emerged, seeking to ensure a true narrative place for journalism. The most common are fact-checking experiences ${ }^{1}$. In addition, organizations have been assembling to crosscheck information, a method in which separate organizations verify the veracity of the same suspicious information.

Projeto Comprova is one of those cross-checking experiences. It derived from an initiative of First Draft, a project of the Shorenstein Center for Media, Politics and Public Policy at Harvard Kennedy School. Coordinated by the Brazilian Association of Investigative Journalism (Abraji), Comprova brought together 24 Brazilian media outlets, as well as journalists' organizations, social networking websites and university groups, demonstrating a joint articulation of various organizations to combat fake news on the internet.

This paper ${ }^{2}$ aims to understand the Projeto Comprova as a legitimization strategy of the journalistic field. It is justified as the initiative combines media organizations in an unprecedented movement, since several companies involved are competitors (Abraji, 2018). The project was touted as an articulated strategy of journalistic representatives in election times.

\section{The journalistic field: discourse and strategies}

The notion of journalistic field encompasses social actors and institutions. It has its own rules and operation laws, understood by the initiates, allowing their perpetuation. Pierre Bourdieu's field theory $(1983,1997,2007)$ provides an important accrual to study journalistic field strategies in order to gain and conserve legitimacy and to provide a broader understanding of what this field represents in today's society.

Although actors' and institutions' actions are not strictly determinant to the field, they are guided by these structures, while contributing to their constitution and maintenance. According to 
Bourdieu (1983, p. 89, our translation), fields are "structured spaces of positions whose properties depend on the positions in these spaces and can be analyzed independently of their occupants' characteristics (partly determined by them)". To the author, although distinct fields have very specific characteristics, some are invariant, which he calls "general field laws" (Bourdieu, 1983, p. 89, our translation). The fields are composed of agents and institutions that occupy positions within them and have general and specific characteristics, and functional laws of their own.

Social fields encompass all aspects of life in society, guiding the agents' actions and strategies acting within them that aim to maintain the field and its positions - or reaching new positions or subversion. This debate is understood as a struggle between agents, in which their capital type and volume determinate their positions. As Catani (2011) recalls, Bourdieu's notion of field cannot be understood without thinking about its interdependence in relation to the concepts of habitus and capital, which are determinant in the field constitution.

Bonnewitz (2003) explains that there are four capital types: economic, cultural, social and symbolic. The first one is constituted by the economic assets and of subject's production. The second one covers intellectual capacities, transmitted in environments such as school and family, and in three states: embodied, in body expression; objective, in the presence of cultural assets; and institutionalized, that is, conferred by institutions. Social capital refers to the social relations of the individual or group in which he/she is inserted. Finally, symbolic capital consists of the rituals that make the subject recognized by the position he/she occupies. It is related to other capital types, as they feed symbolic capital. Different capitals are more or less relevant depending on the specificity of the field.

Thus, the field agents are always immersed in a struggle, in which the strategies developed - dependent on the agents' capital - can be oriented towards the conservation of structures or their transformation (Bourdieu, 1983). This struggle needs to be driven by some common features. Agents must agree on the notion of what is worth disputing. That is, all the subjects that compose the field has to understand the specific capital of it. These subjects develop an agreement that maintains the field structurally conserved.

Moreover, for a functional field, based on the recognition of this dispute among agents, they need to endow habitus, a "system of 
dispositions acquired by implicit or explicit learning that functions as a generative schemas system" (Bourdieu, 1983, p.94, our translation). Habitus is configured as an adjustment of the agents' conduct, an invisible conductor that produces the actions' orchestration, a knowledge and a being, the materialization of embodied memory and a "legacy" for later generations (Bourdieu, 2007). Habitus generates, explicitly or not, the agents' strategies. In fact, habitus works perfectly when agents, who are no longer fully aware of their role in the field, naturalize it.

This is what Bourdieu (2007) calls symbolic power. It is, at the same time, a seeing and a believing, a power exercised without physical force by structured and structuring forces, which configure the imposition of order as natural, masked. Symbolic power "is exercised only if it is recognized, that is, ignored as arbitrary" (Bourdieu, 2007, p.14, emphasis added, our translation), as it acts in the reproduction of belief. It contributes to the maintenance of subordinations, habitus and field. This is what is at stake in the internal field struggles.

Journalism, influenced and marked by academic and scientific fields, has been recognized as a professional field, even though journalism qualification is not mandatory for the professional practice in some countries, such as Brazil. Nevertheless, in 2012, nine out of ten Brazilian journalists had higher education in journalism (Mick \& Lima, 2013), demonstrating the importance of qualification in educational institutions for journalists' habitus.

The type of education received in the current Brazilian communication schools lags in relation to the profession's practice in the country. According to Meditsch (1998), this occurred due to the imposition of guidelines on schools, contributing to an increasing distance from academic activities to professional practice, which undermines the legitimacy and consolidation of the journalistic field object ${ }^{3}$.

These considerations lead us to the understanding that in Brazil, although the journalists are highly dependent on their higher education, the guidelines do not cover their professional needs. Thus, various aspects of qualification are established in a practical way, in the daily life of newsrooms, and are apprehended in the form of habitus. With the reduction of the largest newsrooms in the country and mass layoffs over the past few years ${ }^{4}$, the field does not cover the number of professionals graduated each year from journalism schools. 
Many of them, aiming to maintain their role in communication, create economic arrangements alternative from media corporations (Figaro \& Nonato, 2017, Figaro, 2018), sometimes remaining informally. The same happens with recently graduated journalists.

The journalistic field is characterized by the two poles structure: the first one, negative, is the "economic" or "commercial" pole, where news is understood as a commodity to be sold; the second one, positive, is the "ideological" or "intellectual", and places the press as central to a full democracy regime (Traquina, 2005). Journalism would then be an essential public service for citizens to have access to their democratic rights.

For this reason, the journalistic field has relative autonomy in relation to market interests. Since news is considered as a commodity for sale in a news organization, the product must be attractive to both consumers and advertisers. It means that several times the acting criteria will be those considered relevant to maintain the audience. In times of technological convergence, we know the most explicit face of this model, since newspaper companies, at least in Brazil, have not yet found formulas for loyalty subscriptions on the Internet, which would guarantee a stable payment for the news production's costs. There are still difficulties related to the price of commercials in the virtual space, as it increases the range of options for advertisers, undercutting prices. This factor has been intensifying competition for advertisers in news outlets, which increases the weight of marketing interests as opposed to the idea of the public interest.

According to Bourdieu (1997), as it is a field characteristic, younger agents (in this case, journalists) are more likely to defend the profession's values as opposed to sales criteria. By way of explanation, younger journalists, since they have smaller capital inside the field, tend to use subversion strategies, unlike those who have been inside the field longer and have a larger volume of capital and tend to attempt conservation.

In the journalistic field, we have also seen a journalist's organizational growth - young or not - around independent initiatives or alternatives to traditional media models, characterized by distinct economic arrangements and innovation in the production and consumption of information (Figaro \& Nonato, 2017, Figaro, 2018). Journalists, graduated or not and allied with other professionals, have been working in these spaces in search of a new productive model, 
centered on aspects of local or national relevance, ascertainment, distinct hierarchical relations and work in social networks.

The Internet provides space for initiatives of new economic arrangements and for models and formats with innovative characteristics to proliferate, although, as shown in the work of Figaro (2018), several of them have economic and financial problems. On the other hand, there have also been attacks on media outlets - especially the traditional ones - accused of producing fake news. These attacks come from important political figures, such as the current president of the Republic Jair Bolsonaro, but also from distinct citizens who, in disagreement with information published in the newspapers, accuse them of producing fake news. This movement began before the Brazilian election period in 2018 and was fierce throughout it. In addition, as in the United States and Europe, the discussion in Brazil about the leakage of data and personal information from social network users and the hiring of mass message trigger packages for voters has begun, which can influence the spread of information - false or not ${ }^{5}$.

The spread of misleading information - especially on the internet, but not only - is not new. As rumors, this type of information has circulated throughout human history (Reule, 2008). There is still no widely accepted definition of what is understood by fake news, and this concept has been disputed in recent research. The attention to the issue is increasing especially because of the possible political and electoral impact of its dissemination.

Allcott and Gentzkow (2017, p. 213) define fake news as "news articles that are intentionally and verifiably false, and could mislead readers". Therefore, this excludes

1) unintentional reporting mistakes (...);2) rumors that do not originate from a particular news article; 3) conspiracy theories (these are, by definition, difficult to verify as true or false, and they are typically originated by people who believe them to be true); 4) satire that is unlikely to be misconstrued as factual; 5) false statements by politicians; and 6) reports that are slanted or misleading but not outright false". (Allcott \& Gentzkow, 2017 , p. 214).

From another point of view, Lazer et al (2018) would define fake news as

Manufactured information that mimics news media content in form but not in organizational process or intent. Fake-news outlets, in turn, lack of news media's editorial norms and processes for ensuring accuracy and credibility of information. Fake news overlaps with other information disorders, such 
as misinformation (false or misleading information) and disinformation (false information that is purposely spread to deceive people)". (Lazer et al., 2018, p.1094).

Although there is disagreement between the two views presented, the main concern that guides these definitions lies in the creation of false news. The authors consider that the fake news' problem represents a structural threat, regardless of the amount of shares, which would occur in an individual sphere. According to this point of view, the production of false news always happens intentionally, even though the sharing may not happen this way. Thus, the concern is not to each specific false news story, but to the context in which it is produced.

There is another common point to be highlighted: both propositions center on the definition of fake news in the format that emulates the journalist ${ }^{6}$. This definition, at least in the Brazilian context, is limited because it excludes the use of out-of-context or exaggerated information, for example. In addition, what has often been called fake news includes texts, photos, and videos that circulate through social media and messaging applications. It is the case exemplified by the article "Vídeo foi editado para deturpar fala de Lula sobre "ideologia do PT" ("Video was edited to misrepresent Lula's talk about 'PT ideology"), published by Projeto Comprova on October 10, 2018. The following text is from the publication:

\begin{abstract}
A video allegedly hidden by the PT in which former President Luiz Inácio Lula da Silva would reveal the party's "true ideology" is false. The images, which have been circulating on social media since 2017 and got viral again within a week of the 2018 elections, were edited and manipulated. The context was misrepresented, and the message is totally different from Lula's original speech.

'This video was kept under lock and key by PT and delivered by Palocci,' says one of the posts that reproduced the manipulated images. Another post of the same video is titled: 'Do you know the true ideology of PT?'." (Comprova, 2018, our translation)
\end{abstract}

In an attempt to demarcate a more focused position on the Brazilian reality, Ribeiro and Ortellado (2018) state that there is a fine line between truth and lies, and therefore use the expression "combat information" to refer to what has been called fake news. They would be produced in a hyper-partisan media context, due to the polarization of the public sphere, which promotes the restriction of debate around positions that individuals already have. This situation expands with the automated operation of social media sites 
and applications. According to the authors, the narratives produced in these spaces are also polarized.

Accusations that traditional Brazilian media outlets produce fake news, as well as the circulation of various types of "combat information" on social media sites and applications, affect journalism as a field, which faces not only a financial problem but also a credibility problem. The newsroom reduction scenario, the practice of creating headlines focused on the extreme uniqueness of news and publishing information prior to its verification especially public figures' statements - turn journalism an easy target for such accusations. In this circumstance, the journalistic field has sought, through the association of journalistic organizations, strategies that legitimize it to society, in order to guarantee its permanence and relevance.

The notion of legitimation, according to Berger and Luckmann (2004), is defined as a process of objectification in the sense of "second order". Its function is to turn institutionalized objectifications "objectively accessible and subjectively plausible" (Berger \& Luckmann, 2004, p.127, our translation). In addition, it has integration purpose. Legitimacy justifies the institutional order. This happens through values, but also through knowledge. Therefore, it is necessary not only to know that the narrative of the journalistic field is true, then positive - receiving the attribution of a value - but to understand why it is true - because there is checking, verification, for example.

Thus, the authors explain that the symbolic universe encompasses all socially objectified meanings. It also legitimizes the institutional order by the hierarchy of human experience, categorizing phenomena and types of individuals into hierarchy. It still orders history, linking humanity to past and future, its predecessors and successors, in a meaningful totality. In this way, the symbolic universe of the society members already existed before them and will exist permanently thereafter. The legitimations always act to maintain the symbolic universe under discussion.

Afterward, we discuss Projeto Comprova as a legitimization strategy of the journalistic field. The purpose of gathering organizations in the project is explicit as we seek to understand how these strategies unfold, ensuring credibility through discourse. 


\section{The Comprova strategy}

Projeto Comprova began its activities on August 6, 2018. The last check was published on October 28 , in the second round of the 2018 Brazilian general elections ${ }^{7}$. After announcing its closure, Comprova resumed its activity in 2019 , checking information about the federal government's public policies. In the beginning, the project presented itself as a collaborative work between outlets during the Brazilian electoral period.

The project was developed by the Brazilian Association of Investigative Journalists (Abraji), based on the initiative of the US laboratory First Draft, linked to Harvard University. It involved some of the country's traditional journalism organizations, as well as outlets that could be considered alternative economic arrangements and a popular newspaper. As part of Comprova the groups NSC Comunicação and UOL; the newspapers Folha de S.Paulo, O Estado de S. Paulo, Correio do Povo, Jornal do Commercio, O Povo and Metro Brasil8; the magazines Exame, Nova Escola, Piauí and Veja; the television channels Band News, Band TV, Canal Futura and SBT; the radios Band News FM and Bandeirantes; the AFP news agency; and the digitals Nexo Jornal, Poder360, Gazeta Online, GaúchaZH and Gazeta do Povo'.

Other entities and organizations involved were Projor ${ }^{10}$, Google News Initiative'1, Facebook Journalism Project ${ }^{12}$, National Newspaper Association (ANJ) ${ }^{13}$, David Rockefeller Center for Latin American Studies at Harvard University, Aos Fatos Brazilian factchecking agency, Armando Alvares Penteado Foundation (FAAP) ${ }^{14}$, RBMDF Advogados Brazilian law firm, CrowdTangle digital monitoring platforms, NewsWhip, and Torabit, and social networking companies Twitter and WhatsApp.

This is not First Draft's first crosscheck initiative, which has created similar projects in other countries, such as CrossCheck Nigeria, UK Election Watch and, in France, CrossCheck. In all these places, there were similar characteristics, that consisted especially in gathering companies to "identify and weaken the sophisticated techniques to manipulate and disseminate misleading content that we see emerging around the world" (Comprova, 2018, our translation).

The journalistic field uses several strategies to legitimize itself to society. One of the main strategies is credibility, as pointed out by Carvalho (2010), based on a review of the institutional legitimation 
strategies ${ }^{15}$ of journalism. Credibility is achieved through an agreement between journalism and society, which allows a trust relationship establishment. It is the communication contract of which Charaudeau (2006) speaks, established as an ideal of journalistic discourse.

Credibility is the result of reliability attributed to journalism and journalists - as agents of the field - by other subjects. Thus, the legitimation occurs in the journalist's act of saying. Credibility and legitimation constitute the symbolic capital of journalists. The credibility of journalism and journalists is narratively built. An accurate and, therefore, true journalistic production is assumed, based on "credibility (authority of those who witnessed/saw/is exempt/objective, etc.)" (Guazina, 2013, p. 6, our translation).

In addition, artifacts are used to ensure objective journalistic language and the reinforcement of the social mediation function of journalism, produced by self-reference, which also plays the role of legitimation strategy. According to Carvalho (2010, p. 42, our translation),

\begin{abstract}
Through the news texts, this process takes place by the search for these effects of truth; in editorials and promotional practices, self-referentiality is invoked to draw attention to its mediating function. Therefore, journalistic organizations daily subscribe to the pattern that consolidates them as companies in an industry whose product is information, and institutionally legitimizes them as belonging to an institution. (Carvalho, 2010 , p. 42, our translation).
\end{abstract}

Speed is another strategy in this field, in which information is valued for its currentness and more clearly exemplified in the search for the "scoop" (Bourdieu, 1997). Breaking the news before the competitor guarantees the newspaper - and journalists - a specific kind of symbolic capital.

The arrival of the internet has brought a change in the conception of time in journalistic work. If in print journalism, current implied, at least, the publication of the daily newspaper the next day, in digital, current is what happens now. In this circumstance, in increasingly lean essays and poor working relationships (Deuze \& Witschge, 2015), statements - especially from politicians and influential personalities - are published without verification. It is published abundantly and all the time. What is commonly referred to as declaratory journalism becomes the rule, especially in companies that produce daily journalism.

When the credibility of the journalistic field is contested, one of the strategies that underpins the journalistic field is challenged, 
putting it at risk because it is no longer the place of truth production. It is the case of the accusations that media companies produce fake news, as well as the actual production of exaggerated or misleading content, as in the combat information landscape (Ribeiro \& Ortellado, 2018) we experience.

The journalistic text, which usually presents itself as objective, ready, done, finds in the clarification of the verification process a possible way out for the field's relegitimization. In fact, there is nothing new in cross-checking information. The main difference we identify in these new models, such as crosscheck, is narrative - at least when we consider the existence of an ideal journalistic work, always concerned in verify information.

Next, we seek to identify the strategies of credibility, selfreference and speed in three texts published by Projeto Comprova. We are aware that the small number does not allow generalizations about the checking process. However, our intention is to observe their recurrence in a small number of articles in order to identify these strategies in Comprova's speech about itself and about the process of news construction in these cases. The subjects' selection is due to the centrality that the themes they cover are acquired for the debate in the Brazilian electoral period. The first one, on October 1, 2018, two days after protests against candidate Jair Bolsonaro were reported in more than 100 Brazilian cities. The second date, on October 23, 2018 addresses information circulated on social media at the election process' time, questioning the reliability of electronic voting machines used in Brazil. Finally, we also selected a text published on the "About Comprova" tab, as it is interesting to observe the way Projeto Comprova presents and talks about itself.

In Projeto Comprova's crosscheck experience, there is a concern for detailing the process. Firstly, the companies' essays that cross-checked the information in a movement that refers to the self-reference strategy is specified. Secondly, the steps taken by organizations throughout the verification process are pointed out. This is a feature that can be understood as a credibility strategy. The following text exemplifies this process: "Comprova had access to the metadata of Miguel Schincariol's original file and was able to verify the original date the picture was taken: 4:28 pm on September 29, 2018." (Comprova, 2018, our translation) The explanation of how this information was verified - through access to the image file metadata - seeks to confer confidence through the use of the 
credibility strategy. It is assumed that if the information has been ascertained, it is necessarily true because verification is intrinsic to the cross-checking process. Checkers not only verify the information, but also explain how the process occurred.

The highlighted excerpt is part of the article "Crowd photo at Largo da Batata is in protest against Bolsonaro and not the 2017 Carnival" 16 , October 1, 2018 (our translation). It was checked by Veja, Poder 360, Nexo Jornal, SBT, Correio do Povo, Gazeta do Povo, UOL, Folha de S.Paulo, NSC Comunicação, O Povo, Estadão, Gazeta Online, $A F P$, Jornal do Commercio, and Band. The self-reference strategy is clear in the outlets' presentation that performed the verification.

The article mentioned also uses objective language in order to provide an exemption idea. The opening paragraph of the text is written in an impersonal tone, a characteristic that aims to distance journalistic discourse, as shown in the following example.

The claims and montages claiming to be from Carnival photos of the protest against the candidate Jair Bolsonaro (PSL) at Largo da Batata, in São Paulo, on Saturday, September 29, and that are circulating in groups of WhatsApp and on social media like Facebook, are false. The messages use an article with an old photo of Estadão about the Carnival held in the same place in 2017 (Comprova, 2018, our translation).

The use of objective language is a characteristic used by Projeto Comprova as a credibility strategy. Thus, the journalistic narrative seeks to place itself as a place of truth production. As Carvalho (2010) demonstrated, this characteristic aims to reaffirm the social function of journalism as mediator. Projeto Comprova, as an organization in the journalistic field, assumes that there is a truth that has been verified and proven, where the steps are described in order to ensure the reader's knowledge.

The speed strategy also appears in Projeto Comprova's article. However, checking is a slower process than daily journalism, as it must meet minimal verification aspects before a story is published. However, as in this example, present facts are guided, seeking for factuality.

To demonstrate veracity, the use of sources - especially officials - plays an important role when checking, because they reinforce the information being confirmed or disproved. It is a common practice of journalism that invites those who have the authority to speak. In the checking experience, this feature remains a guarantee of consistency and veracity, acting as a credibility strategy. An example is the article "Auditoria 
em urnas apreendidas no Paraná concluiu que não houve fraude" ("Audit of seized ballot boxes in Paraná concluded that there was no fraud"), October 23, 2018.17 The check was performed by NSC Comunicação, Nexo Jornal, GaúchaZH, Gazeta do Povo, Band News, Poder 360, SBT, O Povo, Jornal do Commercio, Folha de S.Paulo, and Gazeta Online.

\begin{abstract}
To check the audio, Comprova contacted the Superior Electoral Court (TSE) and the Paraná Regional Electoral Court (TRE-PR), who informed that on Thursday, 18 , at $2 \mathrm{pm}$, a public hearing was held to install the ballot boxes audit of the 1st Electoral Zone of Curitiba belonging to sections 654, 655, 664, and 674; from the 178th Curitiba Electoral Zone, the ballot box belonging to section 114; and the 9th Campo Largo Electoral Zone, belonging to section 292. (Comprova, 2018, our translation).
\end{abstract}

The sources used to provide credibility to the information are the Superior Electoral Court and the Regional Electoral Court of Paraná. The specificity of these sources lies in their authority on the article subject - the ballot box audit conducted in the state of Paraná. Moreover, once again the presentation of each of the journalistic organizations responsible for cross-checking this information acts as a self-reference strategy.

The act of narrating part of the verification process also configures a legitimation strategy for its remissive and selfreferential character. This supports the construction of the emphasis on journalism's social function in a social mediation place. While the news' construction process is reported, the outlet demonstrates its concern about the information quality presented to the public, resuming the communication contract commitment.

This technique was already accepted in some journalistic reports, especially those of human interest, which allows the reporter greater creative freedom in the newsroom. If checking experiences are highlighted, it is because there is a perspective journalism change in this regard. This change is narrative and of emphasis, at least when it is taken survey as a central part of journalistic work.

Self-reference is also central to the presentation of Comprova as an outlet, demonstrating itself as a place of truth production. The text on the "About Comprova" tab, that presents the project, states: "The purpose of Comprova is to identify and weaken the sophisticated techniques for manipulating and disseminating misleading content that we see emerging around the world." (Comprova, 2018, our translation). In addition, it presents in its guiding principles rigor, integrity and impartiality, independence, transparency and ethical 
responsibility. They also act as a credibility strategy because they provide a veracity impression of the material published by the Projeto Comprova, therefore legitimating them.

This reassertion of the legitimate place of the checking process and even broadly of journalism, reinforce its role in weakening false or misleading information spread on the Internet. It presents itself as the field capable of pointing the truth, providing credibility to the information disclosed. Comprova peruses to understand that the news produced by the project and - by journalists - are true, credible. On the other hand, those that circulate in online social media and messaging applications have potential to be false, misleading and unreliable sources. In this case, there is a reaffirmation of the role of journalism, with the purpose of legitimization.

\section{Final considerations}

This work aimed to propose an approximation with the comprehension of Projeto Comprova as a strategy to legitimize the journalistic field. Based on the social fields' theory, we seek to understand the position of journalism in society and to propose a perspective to understand Projeto Comprova' experience, which is different of the classical journalism practices in some aspects, at the same time as it is similar to them in other ones.

Checking information by verifying speeches and events is one of the basic prerogatives of professional journalist practice. However, the economic difficulties that led to layoffs and leaner newsrooms, as well as the need for "real-time" publishing, put this precept in the background. Thus, the speed and the search for the "scoop" acquire greater centrality. It impacts the journalism product, especially daily journalism. Verification becomes a privilege of weekend articles or magazines, as well as independent and alternative models for large media organizations, often created from the willingness of journalists to work at a different pace, as shown by Figaro (2018). Not falling into a category such as daily journalism, these initiatives have sometimes done a careful job of different formats and agendas that do not become central to other business models in journalism.

Added to this process of economic and organizational order, there are still the accusations the press has been suffering, in an attempt to delegitimize the journalistic field. Consequently, the journalistic 
field is losing its position of the institution which tells the truth. Organizations then need to resort to strategies that put them back in that position. These strategies, identified in this article as credibility, self-reference and speed, were already recurrent in the classic models of news production. Nevertheless, here they acquire prominence, due to the narrative modifications that the focus on checking confers.

There is still a struggle between the agents of the field, who do not always agree with the hegemonic place of journalistic production, but are alert to values derived from an ideal of journalism that collaborates with society and democracy. They are in the new arrangements of journalistic work, such as those studied by Figaro (2018), but also in the newsrooms considered traditionalists.

In checking projects, especially in the crosscheck model, the focus is on the verification. The process is emphasized, the steps the information goes through before being released are narrated. Possible inconsistencies are pointed out in an attempt to demonstrate to the reader the reasoning of the verifiers to reach the final information - proof of the truth or falsity of a content, in order to ultimately promote the legitimacy of the field in a broader way.

In this case the very idea of news is changed. If previously suspicious information was examined as false, there was no news to be disclosed. In checking experiments, such as fact-checking and crosschecking, characterizing information as false is the news itself.

However, the main modification is narrative. The textual construction with emphasis on the process, investigation and detailing was always restricted to the great reports. Still, this description occurs with caveats, because the journalistic narrative is built to be read as true, so then there is no doubt. Explaining in many details the verification process could, according to this reasoning, open space for questions. The ideal narrative is one and presented finished. The narrative produced by Projeto Comprova uses mechanisms that allow the reader to move on in the news as a story. Not that the story is not told in daily journalism, it is. In the narrative directed to the investigation, the history and the process are assumed to have informative value.

Daily journalism, in general, has not made use of this narrative artifact, which is restricted to isolated models. The practice of demonstrating verification procedures, if retracted to cross-checking experiences, can turn journalistic work to do not seem as verification result and, ultimately, of a story to be told. Restricted to temporary experiences, journalism's legitimation strategies go unnoticed by a significant portion of society 
that seeks information and has been obtaining this information through journalistic products or not. In a society where combat information prevails, it also includes those who get informed by news deemed false.

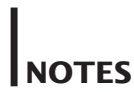

1 Fact-checking is a model that emerged in the 2000 s for speech and information verification. In Brazil, three agencies are certified by the International Factchecking Network (IFCN): Lupa, Estadão Verifica, and Aos Fatos. The work of Spinelli and Santos (2018) discuss the use of the method to combat fake news.

2 This study was funded by the Coordination for the Improvement of Higher Education Personnel - Brazil (Capes) - Financing Code 001.

3 In Brazil, journalism graduation is set by the National Curriculum Guidelines for the Journalism Course. They were produced in 2009 by a committee of experts from various universities and a communication company and approved by the Ministry of Education (MEC) of the Federal Government in 2013. The document separated the journalism course from the Social Communication area, no longer being a qualification and becoming a specific bachelor course (MEC, 2013). The resolution that approved the guidelines also defined the scope of the pedagogical project, curricular organization and institutional evaluation system of journalism courses, including the obligation to complete the course and internship. The year of commission formation for the elaboration of the guidelines coincided with the year in which the plenary of the Supreme Federal Court (STF) declared unconstitutional the requirement of a journalism diploma and the professional registration for professional practice. For a discussion of the professional profile provided by the National Curriculum Guidelines for the Journalism Course, see Faccin and Ferreira (2018).

4 The survey "A Conta dos Passaralhos" conducted by the website Volt Data Lab has been counting the layoffs of journalists and other workers of journalism and communication companies since 2012.

5 In 2018, Facebook founder and CEO Mark Zuckerberg was called upon to provide clarification to the US Congress and the European Parliament about a leak of personal information from 87 million users, which according to investigations were used by the political consultancy Cambridge Analytica policy in Donald Trump's cam- 
paigns for the United States Presidency about the exit of United Kingdom from the European Union, known as "brexit" (EFE Agency, 2018). In Brazil, one of the relevant cases was the report made by the newspaper Folha de S.Paulo that companies hired mass message firing packages, in support of the then candidate and current President, Jair Bolsonaro. The action is considered illegal as it constitutes an undeclared campaign donation (Mello, 2018).

6 We know there are several possible definitions for fake news. One of these perspectives is presented by Wardle and Derakhshan (2017), who reject the term fake news, preferring to classify information disorder as "mis-information", "dis-information" and "mal-information". We chose not to discuss them here because our focus is not on the false news phenomenon, but on how journalism has been trying to respond to it.

7 During the 2018 elections, Brazil, in a movement similar to countries such as France and United States, saw the relevance of the right-wing Jair Bolsonaro (PSL) candidacy, which brought together forces such as the military, evangelical churches and of a highly liberal group. Thus, he presented himself as conservative in manners, although liberal in economics. In addition, during the election process in August 201 8, former President Luiz Inácio Lula da Silva (PT), a candidate who gathered the majority of the electorate, according to the polls, was prevented from running for the Superior Electoral Court. The prohibition was motivated by the former president's conviction for passive corruption and money laundering in a process that raised questions about the political role of judges and prosecutors.

8 All print newspapers cited here are traditional journalism vehicles and are funded through subscription programs, in addition to the sale of copies, except for Metro Brasil, which is distributed on the São Paulo (SP) subway lines with reduced prices.

9 Nexo Jornal and Poder360 are native digital outlets that can be considered alternative arrangements to traditional ones, even though they do not necessarily identify themselves in these terms. GaúchaZH is a Grupo RBS portal that gathers, since 2017, sites of Radio Gaúcha and the newspaper Zero Hora. Gazeta Online and Gazeta do Povo, although they are only digital, are organized financially in a similar way to the present printed outlets, through subscriptions and advertisements. Gazeta do Povo was a printed newspaper and, since 2017 , is only digital.

10 Porjor - Institute for the Development of Journalism is a Brazilian 
non-governmental organization that carries out projects aimed at reflecting on journalistic practice.

11 Google News Initiative is a European organization created by Google to financially support journalism innovation projects.

12 Facebook Journalism Project aims to fund journalism initiatives.

13 The National Association of Newspapers (ANJ) is a Brazilian entity created in 1979 for the defense and development of the country's newspapers.

14 The Armando Alvares Penteado Foundation (FAAP) is a Brazilian philanthropic entity that operates in the education area.

15 We admit a possible approximation between the concept of field and institution.

16 After the manifestation in opposition to then-presidential candidate Jair Bolsonaro in October 29, 2018, information circulated on social media that images released as records of the manifestations could be from other events. In this article, Projeto Comprova verified if the photo of a crowd in Largo da Batata, in São Paulo (SP), would be of a group of people in the 2017 Carnival. The information was considered false.

17 Information released during the electoral process covered the possibility of fraud in the electronic ballot boxes used in Brazil. This information was supported by a video published by then-presidential candidate Jair Bolsonaro of the Liberal Social Party. He said in a live broadcast on his Facebook page that there would be a concrete possibility of fraud in favor of the Workers' Party's candidate Fernando Haddad.

\section{| REFERENCES}

Abraji. (Ausgust, 6, 2018). Projeto de combate à desinformação nas eleições inicia atividades. Abraji. Retrieved from https://www.abraji. org.br/noticias/projeto-de-combate-a-desinformacao-nas-eleicoesinicia-atividades

Agência EFE. (May, 22, 2018). Zuckerberg pede perdão no Parlamento Europeu por vazamento de dados. Agência Brasil. Retrieved from http:// agenciabrasil.ebc.com.br/internacional/noticia/2018-05/zuckerbergpede-perdao-no-parlamento-europeu-por-vazamento-de-dados. 
Allcott, H., \& Gentzkow, M. (2017). Social Media and Fake News in the 2016 Election. Journal of Economic Perspectives, v. 31, n. 2, p. 211 36. DOI: 10.1257/jep.31.2.211

Berger, P., \& Luckmann, T. (2004). A construção social da realidade: Tratado de Sociologia do Conhecimento. Petrópolis: Vozes.

Bonnewitz, P. (2003). Primeiras Lições sobre a sociologia de P. Bourdieu. Petrópolis: Vozes.

Bourdieu, P. (1983) Algumas propriedades do campo. In: Bourdieu, P. Questões de sociologia. Rio de Janeiro: Marco Zero.

Bourdieu, P. (1997). Sobre a televisão: Seguido de A influência do jornalismo e Os Jogos Olímpicos. Rio de Janeiro: Zahar.

Bourdieu, P. (2007). O Poder Simbólico. Rio de Janeiro: Bertrand Brasil.

Carvalho, L. M. (2010). Legitimação institucional do jornalismo informativo nas mídias sociais digitais: Estratégias emergentes no conteúdo de Zero Hora no Twitter. (Dissertação de mestrado). Retrieved from Manancial (https://repositorio.ufsm.br/handle/1/6315).

Catani, A. M. (2011). As possibilidades analíticas da noção de campo social. Educação \& Sociologia, v. 32, n. 1 14, p. 189-202. DOI: 10.1590/ S0101-73302011000100012

Charaudeau, P. (2006). Discurso das mídias. São Paulo: Contexto.

Comprova. (October, 01, 2019). Foto de multidão no Largo da Batata é de protesto contra Bolsonaro e não do Carnaval de 2017. Comprova. Retrieved fromhttps://projetocomprova.com.br/post/ re_2B5W8XN4gVwb

Comprova. (October, 02, 2018). Vídeo foi editado para deturpar fala de Lula sobre 'ideologia do PT'. Comprova. Retrieved from https:// projetocomprova.com.br/post/re_2B5W8XNqVdpY

Comprova. (October, 23, 2018). Auditoria em urnas apreendidas no Paraná concluiu que não houve fraude. Comprova. Retrieved from https://projetocomprova.com.br/post/re_2B5W8XZLgxkY

Comprova. Sobre o Comprova. Comprova. Retrieved from https:// projetocomprova.com.br/about/about

Deuze, M., \& Witschge, T. (2015). Além do jornalismo. Leituras do jornalismo, São Paulo, v.2, n.4. Retrieved from https://www3.faac. unesp.br/leiturasdojornalismo/index.php/leiturasdojornalismo/ article/view/74

Faccin, M. J. \& Ferreira, S. V. (2018). Formação jornalística e os novos fluxos 
informativos: Uma Análise Do Perfil De Profissional Previsto Nas Diretrizes Curriculares Nacionais. Revista Passagens, v. 9, n. 1, p. 34-49. Available at http://www.periodicos.ufc.br/passagens/article/view/39727.

Guazina, L. Campos em disputa: jornalismo versus política na cobertura do Jornal Nacional sobre o Escândalo do Mensalão. Anais do $11^{\circ}$ Encontro Nacional de Pesquisadores em Jornalismo. Brasília, Universidade de Brasília. p. 1-18. 2013. Retrieved from http://soac. bce.unb.br/index.php/ENPJor/XIENPJOR/schedConf/presentations>.

Figaro, R. (2018). (Org.). As relações de comunicação e as condições de produção no trabalho de jornalistas em arranjos econômicos alternativos às corporações de mídias. São Paulo: ECA-USP.

Figaro, R., \& Nonato, C. (2017). Novos 'arranjos econômicos' alternativos para a produção jornalística. Contemporanea, v. 15, n. 01, p. 47-63. DOI: 10.9771/1809-9386contemporanea.v15i1.21451

Lazer, D. M. J., Baum, M. A., Benkler, Y., Berinsky, A. J., Greenhill, K. M., Menczer, F., Metzger, M. J., Nyhan, B., Pennycook, G., Rothschild, D., Schudson, M., Sloman, S. A., Sunstein, C. R., Thorson, E. A., Watts, D. J. \& Zittrain, J. L. (2018). The Science of Fake News. Science, v. 359, n. 6380, p. 1094-1096. DOI: 10.1126/science.aao2998

Marques, J. (October, 21 , 2018). Folha é a maior fake news do Brasil, diz Bolsonaro a manifestantes. Folha de S.Paulo. Retrieved from https://www 1 .folha.uol.com.br/poder/2018/10/folha-e-a-maiorfake-news-do-brasil-diz-bolsonaro-a-manifestantes.shtml

MEDITSCH, E. (1998). Jornalismo como forma de conhecimento. Revista Brasileira de Ciências da Comunicação, v. 21 , n. 1, p. 25-38.

Mello, P. C. (October, 18, 2018). Empresários bancam campanha contra o PT pelo WhatsApp. Folha de S.Paulo. Retrieved from https://www 1 . folha.uol.com.br/poder/2018/10/empresarios-bancam-campanhacontra-o-pt-pelo-whatsapp.shtml

Mick, J \& Lima, S. (2013). Perfil do jornalista brasileiro: Características demográficas, políticas e do trabalho jornalístico em 2012. Florianópolis: Insular.

Ministério da Educação (2013). Resolução $n^{\circ} 1$, de 27 de setembro de 2013. Retrieved from http://portal.mec.gov.br/component/content/ article?id=12991

REULE, D. S. (2008). A dinâmica dos rumores na rede: A web como espaço de propagação de boatos virtuais. (Dissertação de mestrado). Retrieved from: https://lume.ufrgs.br/handle/10183/13796.

Ribeiro, M. M. \& Ortellado, P. (2018). O que são e como lidar com as notícias falsas: Dos sites de notícias falsas às mídias hiper-partidárias. Sur - Revista Internacional de Direitos Humanos, v. 15, n. 27, p.71- 
83. Retrieved from http://sur.conectas.org/o-que-sao-e-como-lidarcom-as-noticias-falsas/

Spinelli, E. M. \& Santos, J. A. (2018). Jornalismo na era da pósverdade: fact-checking como ferramenta de combate às fake news. Revista Observatório, v. 4, n. 3, p. 759-782. DOI: 10.20873/uft.24474266.2018v4n3p759

Traquina, N. (2005) Teorias do jornalismo: porque as notícias são como são. Florianópolis: Insular.

Volt Data Lab. (August, 7, 2018). A Conta dos Passaralhos: Um panorama sobre demissões de jornalistas nas redações do Brasil desde 2012. Volt Data Lab. Retrieved from http://passaralhos.voltdata.info/

Wardle, C. \& Derakhshan, H. (2017) Information disorder: Toward an interdisciplinary framework for research and policy making. Estrasburgo: Conselho da Europa.

MARIA IVETE TREVISAN FOSSÁ. PhD in Business (UFRCS); Masters in Social Communication (UMESP). Associated Professor on the Communication Science Department of Universidade Federal de Santa Maria. Works in the Social Communication Course and in the Communication PostGraduation Program of UFSM. She researches organizational communication, public relations, organizational culture, strategic communication, communication and citizenship, and social responsibility. Email: fossa@terra.com.br.

KAUANE ANDRESSA MÜLLER. Graduated in Journalism in Universidade Federal de Santa Maria. Master's student in Communication in the same university. Her research is about the Brazilian factchecking platforms strategies to maintain the journalism as an institution. Email: kauaneamuller@gmail.com. 